\title{
Reading Silence
}

\section{[excerpt from Skepticism and Redemption: The Political Enactments of Stanley Cavell]}

LARRY JACKSON

\section{Must We Speak Politically?}

Stanley Cavell roams across a wide range of fields in his first book, Must We Mean What We Say? most obviously those of epistemology, ethics, and aesthetics. But nowhere in the book's ten essays does he advance an explicit political theory. Still, this book, published in 1969 and written over the course of the preceding decade, quietly poses persistent political questions, even in essays on such topics as skepticism and King Lear, Kierkegaard's Book on Adler and Beckett's Endgame, atonal music and ordinary language philosophy. Just who is the "we" spoken of in the book's title (we philosophers? we Americans? we human beings?)? Is there any relationship between democratic equality and the philosophical appeal to our everyday language, as described in the book's eponymous essay? ${ }^{1}$ Does the account that Cavell offers in his piece on Wittgenstein of practices and behaviors shared across cultures-the "whirl of organism" of our forms of life-suggest a nascent theory of human solidarity? 2 Our freedom in language and the responsibility we bear for meaning, topics of the book's opening essays, raise the question of what we might owe to one another and how we might offer-or withhold-it in our choices of words. Is this the beginning of a theory of justice? The concept of acknowledgment, described in the book's final essays as a response to the challenge of skepticism, shifts the

1. I mean here both an equality of subject matter-a democracy of attention-and an equality of speakers, so that philosophy becomes, on Cavell's account, timely and accessible, which is to say, relevant to any and all.

2. Cavell, "The Availability of Wittgenstein's Later Philosophy," in Must We Mean What We Say?: A Book of Essays (Cambridge: Cambridge University Press, 1969), 52. 
problem from what I can know to what I might do. 3 Is this a theory of moral or political action (or both)?

Each of the themes that I identify here as political has something to do with what counts for us, with what we value, with "our cares and commitments" and responsibilities to one another.4 How I make such determinations-how I enact themdetermines who I am. If such themes do in fact run through the varied subjects of Must We Mean What We Say? it is impossible for me to imagine them being politically neutral, examined, as they were, in a decade of war, in years of struggle over rights demanded and denied-an age in which a nation wrestled with its original sins of expansion and inequality, and the world's fate rested more on the accuracy of our intelligence than the wisdom of our leaders. When millions demanded that their voices be heard and their humanity acknowledged, how could Cavell write about lending one's voice to what one says, or of our shared human forms of life, or of the avoidance and the denial of acknowledgment, without meaning it politically?

Must we speak politically? Do philosophers have political obligations, not just as citizens, but as philosophers-obligations that must be met in the writings or teachings that constitute their work? If such obligations can be said to exist, does it make silence about the political crises of their time unforgivable? Or are there times when silence is the most appropriate-the only-response?

Cavell addressed these very questions more than 20 years after the publication of Must We Mean What We Say? in a reading of Ralph Waldo Emerson's essay "Fate," titled “Emerson's Constitutional Amending." It was not Cavell's first foray into Emerson's writings, nor was it his first reading of "Fate," but it did represent the first time that Cavell felt, as he puts it, "forced to emphasize a political theme in [Emerson's] work."5 What made the politics so urgent?

Writing in the early 1990s, the burning issue was not the Vietnam War or the American Civil Rights Movement or even the lingering threat of nuclear weapons,

3. Cavell, "Knowing and Acknowledging," in Must We Mean What We Say?, 238-66 (see n. 2),

4. Cavell, The Claim of Reason: Wittgenstein, Skepticism, Morality, and Tragedy (Oxford: Oxford University Press, 1979), 312.

5. Cavell, "Emerson's Constitutional Amending," in Emerson's Transcendental Etudes, ed. David Justin Hodge (Stanford: Stanford University Press, 2003), 193. 
but the "Heidegger affair": the scandal over then recent "revelations"-none so startling or so new-concerning Heidegger's intimate involvement with National Socialism. 6 For critics of Heidegger the cardinal offense was not that the philosopher had been a member of the Nazi Party (though this was bad enough), but rather that he had remained silent-appallingly so-about the mass exterminations carried out in the death camps. Bad choices might be forgiven, but a proud, untroubled conscience discourages such generosity.

For Cavell the question of Heidegger's politics was a particularly personal one. Emerson, one of Cavell's foremost intellectual influences, was also one of Heidegger's philosophical forebears. The American transcendentalist had exerted a major influence on the early Nietzsche, whose ideas became something of an obsession for Heidegger just at the time of his involvement with the Nazi Party. This is bad company for anyone to keep, but it is an especially unfortunate legacy for the founder of American philosophy. "Does Heidegger's politics-by association, to say the least-taint Emerson's points of contact with it?" Cavell asks.7 But given his own place in that lineage and his sedulous efforts to make the institutions of American philosophy recognize Emerson as a serious thinker, this question of contamination must refer as much to Cavell himself as it does to Emerson.

Cavell approaches the question of whether Heidegger's politics pollute Emerson's own ideas by interpreting another problematic silence: Emerson's apparent failure in "Fate," an essay on human freedom, to criticize the institution of slavery in America. 8 Emerson's opposition to slavery is well known, but his silence in "Fate" about what was, in his time, the single greatest violation of human freedom has struck critics such as Harold Bloom and John Updike as an admission of despair that

6. The publication of Victor Farias's book Heidegger et le Nazisme sparked "the Heidegger Affair." See Victor Farias, Heidegger and Nazism (Philadelphia: Temple University Press, 1991). For a blow-by-blow account, see Thomas G. Pavel, "The Heidegger Affair," in MLN 103.4 (September 1988): 887-901.

7. Cavell, "Emerson's Constitutional Amending," 194.

8. Cavell wrote about "Fate" in 1983, 12 years before "Emerson's Constitutional Amending." "I was myself silent about this question of Emerson's silence when I wrote an essay in 1983 mostly on Emerson's 'Fate' (I called it 'Emerson, Coleridge, Kant'), my first somewhat extended treatment of an Emersonian text. It was seeming to me so urgent then to see to the claim to Emerson to be a philosophical writer, in principle imaginable as founding philosophy for a nation still finding itself, that I suppose I recurrently hoped that Emerson had, for the moment of the essay 'Fate', sufficiently excused or justified his silence in saying there, 'Nothing is more disgusting than the crowing about liberty by slaves, as most men are.” Ibid., 194-95. 
nothing could be done, "that Emerson gave up on the hope of democracy" altogether.9 It is not as though Emerson's silence was absolute: both before and after "Fate" he spoke out publicly-polemically-against slavery. But what Cavell is asking, after Bloom and Updike, is whether this was enough philosophically.10

The answer might at first appear to be no. Referring to a public speech that Emerson gave in 1844, titled "Emancipation in the British West Indies," Cavell argues that "the absoluteness of the American institution of slavery among the forms human self-enslavement takes, hence the absoluteness of philosophy's call to treat it, to recoil from it, is announced."11 Implicit in this reading of Emerson are two assumptions: one, that the goal of philosophy is human freedom, so that philosophical thought and writing should take the form of an intellectual confrontation with enslavement or imprisonment or, as Emerson would put it, fate, in all their forms; and two, that such a confrontation must not be polemical. The problem that "Fate" raises, then, is not whether Emerson the citizen opposed slavery, voted against it, used his skills as a writer and his reputation as an orator to confront it polemically: this is uncontroversial. The problem is whether Emerson the philosopher was able to fulfill the very duty that he had assigned to philosophy itself, that is, whether he treated and recoiled from slavery not just polemically but as a thinker as well. If the meaning of this-a philosophical confrontation with slavery that is not polemical-is not yet entirely clear, it is worth dwelling, for now, on just this question: How could an essay about human freedom written just months after the passage of the 1850 Fugitive Slave Act-a law that effectively expanded the reach of the slave owner to every state in the Union, extinguishing for the slave the very possibility of freedom within the borders of the United States-fail to address this most bald and brutal affront to human freedom? Did Emerson succumb to a despair that compromised the emancipatory ambition of his own philosophical writing? Did philosophy for Emerson cease to be a confrontation with the world, becoming instead a retreat from its ruthless realities? If Cavell's essay on "Fate" is as self-referential as I have claimed, then how he answers these questions will, I argue, shed light on the political themes that I have sought in Cavell's own project.

9. Ibid., 194.

10. For this critique of Emerson, see Harold Bloom, "Mr. America," in The New York Review of Books, November 22, 1984. Also John Updike, "Emersonianism," in The New Yorker, June 4, 1984. 11. Cavell, "Emerson's Constitutional Amending," 210; emphasis mine. 
Cavell's response to the question of Emerson's silence in "Fate," roughly, is this: philosophy cannot but confront slavery. "If slavery is the negation of thought," writes Cavell, "then thinking cannot affirm itself without affirming the end of slavery." 12 Is this just a glib excuse for inaction, a convenient bromide for the morally self-satisfied? I will have more to say about that, but for now I limit myself to only this point. Beyond the question of philosophical influence as it appears in "Emerson's Constitutional Amending," there is another, historical inheritance worth considering when reading Cavell, namely, the legacy of that same absolute institution of slavery, which, at the time that Cavell was writing Must We Mean What We Say? took the form of Jim Crow segregation. Does it too require an absolute philosophical response?13 If something like this were not true of the call to philosophy in Cavell's timeand our own-if unjust wars and irrational hatreds were not incentives to think, it would prove, to quote Cavell, "harder than I could digest."14

But that is not the only reason I will contend that these are, for Cavell, the most pressing incentives to think. Cavell's writings, early and late, show him struggling with the political provocations of his age in a fashion that I consider both fundamental to his project, and ultimately relevant to political philosophy more generally.15 The stalking, subtle presence of the problems of post-war politics in Must We Mean What We Say?-of war and inequality and indifference and the bomb-thus

12. Ibid., 205.

13. Cavell the citizen certainly responded to Jim Crow segregation, participating, for example, in Mississippi Freedom Summer in 1964. See Cavell, Little Did I Know: Excerpts from Memory (Stanford: Stanford University Press, 2010), 429-34.

14. Cavell, "Emerson's Constitutional Amending," 194.

15. Cavell might appear to undercut my argument in his memoir, when he writes: "There came a time during the Vietnam War when I interrupted myself during a lecture, moved to say that I could no more ignore that morning's news, at least to notice it in common, than I would be able to withhold attention to the cry of a child. At the same time I registered my sense that this very acknowledgment signaled the victory of violence over thinking. Then sometimes thinking must turn to destroy its peace, to observe havoc, in order to attract its own protection" (Cavell, Excerpts, 478; emphasis mine). But if philosophy is an argument with one's culture, then such interruptions are no more a suspension of thought than Nora's dramatic exit is a cessation of her argument with Torvald: "[T]he final sound of the slamming door of the house [...] counts not as the interruption of an argument but as its continuation by other means" (Cavell, Pursuits of Happiness: The Hollywood Comedy of Remarriage [Cambridge: Harvard University Press, 1981, 23-24]). Elsewhere, citing Heidegger, Cavell suggests that our oblivion to such provocations is indeed what calls most for thinking: "[T]he thing most critically provoking in our riskily provocative time [is] that we are still not really provoked, that nothing serious matters to us, or nothing seriously, that our thoughts are unscrupulous, private" (Cavell, "Aversive Thinking: Emersonian Representations in Heidegger and Nietzsche," in Emerson's Transcendental Etudes, 141-70 [see n. 7], 144-46). 
provides a window into Cavell's key philosophical concepts and an indication of what his theory of the political might be.

\section{The Interpretation of Politics}

Most commentators on Cavell have either avoided political questions altogether or tallied up those few passages in Cavell's writings where he speaks openly (and, so the assumption goes, anomalously) about political topics and issues: the pages on the social contract or on abortion in The Claim of Reason; the invocations of democracy in his defense of Perfectionism against Rawls in the Carus Lectures; or his occasional treatment of patently political themes in The Senses of Walden. Andrew Norris opens his introduction to a volume on Cavell and political philosophy with an admission that "the very idea that Stanley Cavell's work contributes anything significant to political theory might seem odd," and notes the dearth of writings on the subject. ${ }^{16}$ Stephen Mulhall, in a chapter devoted to politics in his book Stanley Cavell: Philosophy's Recounting of the Ordinary, argues that Cavell's writings on politics were, until later in his career, "much less extensive than his work on aesthetics and morality." ${ }_{17}$ Lawrence Rhu takes the opposite position in Stanley Cavell's American Dream, describing "The Avoidance of Love," the final essay in Must We Mean What We Say?, as a work inspired "by the agony of America's involvement in Vietnam," while arguing that Cavell's later writings are less political, more literary, and more palatable. ${ }^{18}$ Mulhall and Rhu thus share the premise that a rupture occurs somewhere in Cavell's writings, a break that is at least rhetorical, if not entirely thematic.

In this book I offer a political interpretation of Cavell's work that takes his writings as a cohesive whole dedicated to the discovery and creation of an American voi-

\footnotetext{
16. Andrew Norris, "Introduction: Stanley Cavell and the Claim to Community," in The Claim to Community: Essays on Stanley Cavell and Political Philosophy, ed. Andrew Norris, 1-18 (Stanford: Stanford University Press, 2006), 1. Norris writes that only nine of the 214 entries on Cavell in The Philosopher's Index concerned the philosopher's contributions to political theory. I have not attempted to replicate Norris's results, not knowing the precise terms of his search. [Note: This chapter was written before Norris's most recent book, Becoming Who We Are, was published, so it does not grapple with the ideas advanced there.]

17. Stephen Mulhall, Stanley Cavell: Philosophy's Recounting of the Ordinary (Oxford: Oxford University Press, 1994), 55. While I think Mulhall underestimates the importance of the political in Cavell's work, his reading has set the tone for those that have followed, including Norris's.

18. Lawrence Rhu Stanley Cavell's American Dream: Shakespeare, Philosophy, and Hollywood Movies (New York: Fordham University Press, 2006), 25.
} 
ce for both politics and philosophy. While the centrality of America to Cavell's project certainly draws on the history and culture of the United States, most of all on our "sacred" texts-our movies and our literary laments for lost promises (read: Walden)all the world is, once again, for Cavell, America. Which is to say that he understands by this word an idea or a site for humanity rather than any specific geographical location, historical narrative, or political identity. Cavell's concept of American subjectivity will, therefore, be at once a theory of political action and of human redemption: to speak with this American voice is to "stand for humanity."19 If this idea of America sometimes bears a close resemblance to the history and geography and politics of a place called the United States, it is all the more closely related to a state of immigrancy or exile that millions have found here, a way of being in no place, which only means that the idea of America is, for Cavell, the quest for utopia.

My argument thus has bearing on how we interpret the entirety of Cavell's philosophical project and on how we understand his theory of the political. I will pursue three interwoven lines of interpretation, which I call, prosaically enough, the thematic, the aesthetic, and the theoretical.2o The first of these, the thematic, is the most important and the most controversial [...]. There are three tasks associated with this first line of interpretation:

(1) To describe how we ought to read Cavell by examining four exemplary readings: "The Politics of Interpretation," "Austin at Criticism," "Declining Decline," and "Emerson's Constitutional Amending." In these avowedly political essays spanning his career, Cavell describes his own interpretive strategies, even providing a reading of one of his own earlier essays. From this I develop a loose network of concepts that I use throughout the book as an interpretive key [...].

(2) To identify and analyze the political themes found in Cavell's earliest writings, the essays in Must We Mean What We Say? [...]

19. Cavell, "Being Odd, Getting Even (Descartes, Emerson, Poe)," in Emerson's Transcendental Etudes, 83-109 (see n. 7), 93.

20. Each of these labels is flawed, so I offer them here only as useful signs, not as major landmarks. Thematic only accounts for (at best) two of the three tasks I assign to it, failing to describe the work of developing interpretive keys; aesthetic is perhaps the best of the three labels, but following on themat$i c$, it might suggest that I am analyzing the aesthetics of Cavell's writings rather than a particular aesthetic idea that Cavell employs; and theoretical says virtually nothing by saying too much entirely, though it is, perhaps, for its banality, the most accurate. 
(3) To show how these themes determine the course of Cavell's philosophical inquiries in the texts that follow them. As I have suggested already, Cavell makes an appeal to everyday political problems in formulating his seminal philosophical concepts and as a way of achieving a theoretical account of what politics is, a strategy analogous to ordinary language philosophy's appeal to what we say in our day-to-day lives as a way of addressing philosophical problems. Having identified these themes I will argue that the creation and discovery of a political and philosophical American voice or subjectivity leads Cavell in two directions: a reading of Thoreau and (later) Emerson, and the study of cinema (which leads, in turn, to a study of opera, a source of inspiration for American movies). 21

The second line of interpretation, which I call the aesthetic, examines the dramatic genres, plots, and personae (or types) that Cavell associates with politics: the tragic $[\ldots]$, the cinematic [...], the prophetic [...], the operatic or melodramatic, and the comedic [...]. This might be thought of as the book's secondary argument: that Cavell describes politics as staged or enacted, so that our experience as audience members is actually a kind of political education. ${ }^{22}$ As he argues in The World Viewed, when our lives have become theater, the only intelligible explanation of our condition will itself be dramatic. 23

My third line of interpretation, the theoretical, is the overarching task of this book [...]: the development of a Cavellian theory of the political. I claim that the central conceptual dynamic in Cavell's thought is the relationship between two poles of human existence: skepticism and redemption. Skepticism is to be understood here as a lived condition rather than a (purely or primarily) intellectual problem. The idea of "living our skepticism" is Cavell's most drastic divergence from other accounts of Cartesian doubt. He criticizes the academic skeptic for reducing an existential state to an epistemological puzzle, as though the quest for certainty were but a clever distraction

21. The other reason for turning to opera is the prominence of the voice. It is worth pointing out that Cavell's studies of cinema make almost no mention of movies prior to the advent of "talkies" (a term that appears often, and anachronously, in his writings on film), suggesting that the primary characteristic of cinema as a medium is not the image.

22. See Stanley Cavell, The World Viewed (Cambridge, MA: Harvard University Press, 1971), 91-94. 23. Ibid., 92. 
from implacable human anxieties, or a last, desperate attempt to hold on to a receding world. You might as well try to bottle the waning tide. What, then, is skepticism?

Cavellian skepticism is a condition of alienation from the world and from others that takes the form of a crisis of acknowledgment and an avoidance of responsibility. On this reading, the key feature of Descartes' skeptical recital in the Meditations is the malaise-or madness-that enables his descent into hyperbolic doubt. The first Meditation depicts the world as a disquieting nightmare. The reliability and familiarity of home give way to the false and fickle stirrings of a malicious demon, rendering its every fact and feature a hostile phantom.

While Cavell views skepticism as a constant human possibility, he also argues that it has distinct historical and political causes and manifestations. And it goes by many names: Coleridge's “dejection,” Thoreau's “quiet desperation,” Emerson's "secret melancholy," Marx's “estrangement.”24 Dante's dark woods are more important to an account of the experience than anything brooded over in Hume's study. And more important than Dante's woods will be Thoreau's.25

Each of these chroniclers of the uncanny describes a world in which things do not add up. Like Descartes', theirs is an account of horror, depicting a senseless, unstable reality, complete with zombies and madmen.26 But unlike Descartes, they do not restrict this state to the unreliability of the senses or the frivolity of opinion. For them, skepticism persists as a shared mood, a zeitgeist in which objects and people have been miscounted or valued wrongly, so that they are not what they seem to be. Faced with a world that is distant and chaotic, these writers find no place for human

24. Cavell frequently links skepticism with mourning as well. See Tammy Clewell, "Cavell and the Endless Mourning of Skepticism," in Angelaki: Journal of the Theoretical Humanities 9.3 (2004): 75-87. A more problematic formulation of this interpretation of skepticism is Heidegger's "bedimmed averageness," which Cavell also invokes-see, e.g., "The Philosopher in American Life (toward Thoreau and Emerson)," in Emerson's Transcendental Etudes, 33-58 (see note 7), 39. The problem, of course, is that Heidegger uses this phrase in section 27 of Being and Time, which is not only one of the most overtly (and uncomfortably) political passages in the book, but is also among the most impoverished philosophical accounts of human plurality that I have encountered. The kind of society that Heidegger condemns in those pages-bustling, messy, disordered-is precisely what I wish to affirm in this work. For more on the politics of this section of Being and Time, see Peter Sloterdijk, Critique of Cynical Reason (Minneapolis: University of Minnesota Press, 1988).

25. Cavell, "Declining Decline," in This New Yet Unapproachable America: Lectures After Emerson and Wittgenstein, 29-76 (Chicago: The University of Chicago Press, 1989), 36-37.

26. Madness and all species of the undead (e.g., ghosts and zombies) will be important themes in my discussion of Emerson and Thoreau. Dante's sojourn into hell provides its own share of horrors. Specters and zombie commodities haunt Marx's world. 
desires and voices, while those who harbor them are but specters amid the shifting shadows.

Redemption, which is never final or absolute, and remains, therefore, a constant human ambition, requires an enactment of your own existence, recalling the claim to exist that, in Descartes, takes the form of the cogito. 27 The difference between Cavell and Descartes-the reason why this is an enactment of (rather than a claim to) existence-is that redemption must, like skepticism, be lived, which is to say that it concerns what we do, rather than what we know. Cavell thus describes redemption in terms of what he calls acknowledgment, a phenomenon that is related to knowledge while also going beyond it: to acknowledge my pain is not just to understand it, not to verify it, but to respond to it (by alleviating it, for instance).28 And to acknowledge my pain is to acknowledge me-here, now, this singular being in this specific set of circumstances. And with me, goes my humanity. After all, what is made of stone does not feel pain, which is why some might wish to trade their flesh for it.29

Enacting my existence, then, means making a place in the world by petitioning some other to acknowledge my voice and my desire as a human subject.3o I may use words to issue my demand, or I may show it. My demand may refer to some specific fact in the world or some particular need that I have, or it may be more nebulous. I hope that it proves to be more than mere whimsy, but I cannot know until I have made the attempt: in the scene of acknowledgment my trust in what I have to say or show-my trust in myself-necessarily precedes my knowledge of it.31 Whatever the circumstances, Cavell argues that I enact my existence in a staged confrontation with someone else. His concept of redemption thus resembles the demand that occupies the place of the cogito in Marx: "I am nothing and should be everything," only, in this iteration the actor is no longer the Proletariat.32 It is America.

27. Cavell, "Being Odd, Getting Even," 88-90.

28. Cavell, "The Avoidance of Love," 257.

29. See Ludwig Wittgenstein, Philosophical Investigations, trans. G.E.M. Anscombe, P.M.S Hacker and Joachim Schulte (Chichester: Wiley-Blackwell, 2009), §283.

30. The secularization of sin or perdition as skepticism is, of course, taken over from Descartes; the secularization of the concept of redemption is due to the unavailability of God, after Descartes, to be my other. Cavell's secularization of the theological will be an important theme in what follows.

31. The allusion here is to Emerson's "Self-Reliance." It occurs throughout Cavell's writings and this work. See Cavell, Conditions Handsome and Unhandsome: The Constitution of Emersonian Perfectionism (Chicago: The University of Chicago Press, 1990), 12.

32. Karl Marx, "Contribution to the Critique of Hegel's Philosophy of Right," in The Marx-Engels Reader, ed. Robert C. Tucker 53-65(New York: W.W. Norton \& Company, 1978), 63. 
Since skepticism is in fact alienation from the world and from others, redemption through this staged confrontation, the scene of acknowledgment, also takes the form of reconciliation, or what Cavell calls a "return to the ordinary." 33 This is not necessarily reconciliation with the person I address when issuing my demand: conflicts may not end so easily (or at all). It is, rather, reconciliation with a world that, so long as I remained mute, would not exist for me: it is not $m y$ world until it includes $m y$ voice. And so, my demand is actually to have my voice heard both in affirming my own existence and in "calling back the world." 34 The connection between these two is Cavell's Kantian premise that to be is to judge the world. By enacting my existence I enact this judgment. (The voice plays the same role for Cavell that transcendental apperception plays for Kant: the simultaneous presentation of world and self.)

But what does it mean to bring back the world, to return to the ordinary? It is among the most enigmatic, challenging concepts in Cavell's writings, appropriate enough to the melancholic reveries of Romanticism ("Five years have passed; five summers, with the length / Of five long winters ...”), but hard to nail down as a philosophical concept, let alone a political one.35 This is how I see it. In speaking, I take responsibility for the world. I express my desire for intimacy with it, for the right to judge it, name it, make it my home, as though I were Adam in the Garden. But this is not a return to (or of) things as they are: my desire entails "recounting" or revaluing things and people. The world is not only interpreted here: it is changed. Cavell borrows the Emersonian "transfiguration" of Kant's transcendental philosophy, where the judgment of the world is both the epistemological constitution of it that Kant delineates in the first Critique, and the expression of (Romantic?) disappointment with this epistemology, expressed as a wish to change the world altogether, the dissatisfaction described in Emerson's "Experience" as knowledge of the contrast between "the world I converse with" and "the world I think"-knowledge that I do not synthesize, but suf-

33. Cavell, "Texts of Recovery (Coleridge, Wordsworth, Heidegger ...)," in Quest of the Ordinary: Lines of Skepticism and Romanticism (Chicago: The University of Chicago Press, 1988), 53.

34. Cavell, "Opera and the Lease of Voice," in A Pitch of Philosophy: Autobiographical Exercises (Cambridge, MA: Harvard University Press, 1994), 151.

35. William Wordsworth "Lines Written a Few Miles Above Tintern Abbey," in William Wordsworth: The Major Works, ed. Stephen Gill (Oxford: Oxford University Press, 1984), 131. 
fer.36 You might describe this as the claim that Kant's transcendental philosophy is not transcendental enough. Democracy is Idealism on these shores, the making of a new world. It is as though my desire brings the world back to life, animates what I once took to be unworthy of-or hostile to-it.37 Another word for it, which will come up throughout Cavell's writings, is rebirth-both my own, and my world's.38 Rebirth follows the craving for intimacy that is desire.

The claim-implicit in the demand for acknowledgment-that I have a right to voice this new desire for a new world, accounts for the confrontational nature of the scene of acknowledgment, what Cavell calls, "the argument of the ordinary." But it is this voicing that, however contentious, constitutes the essence of human freedom, even when the acknowledgment that you demand is not to be granted. Freedom lies in the assumption of responsibility for the world, for yourself, and for your society, which is why this staged confrontation is the start of, and a necessary component in, what Cavell calls, in his response to Rawls, "the conversation of justice." How can this be political?

\section{Skepticism and Redemption}

In this book, I treat the lived condition of skepticism, as I have described it here, as an explicitly (though not exclusively) political experience. The political relevance of other minds skepticism-the question of whether another person has ideas, feelings, or even a mind as I do-should be obvious. When the harmless suspicions, anxieties, and snobberies of everyday life become so exaggerated, is there any reason not to deny others justice or life? To say that we can live our skepticism with regard to other minds is to say that we do not value others as we should, that society, or the world, is now violent and unjust.

36. Ralph Waldo Emerson, "Experience," in The Essential Writings of Ralph Waldo Emerson, edited by Brooks Atkinson, 307-26, (New York: The Modern Library, 2000), 326. If Romanticism is the desire to overcome our estrangement from the world, as Cavell argues in In Quest of the Ordinary, then Marx and Freud clearly belong to that tradition: both bridge the distance between us and the world through a transformation-of the world in Marx-of the self in Freud. For Cavell, this is not a disjunctive proposition.

37. Cavell, "Texts of Recovery," 52-53.

38. Cavell, "Declining Decline," 63-64. 
Less obvious is the political significance of material object skepticism, the idea that things may be unknowable or even nonexistent. The politics of material object skepticism rests on the notion that our relationship with things in the world is based on the value they have for us, and that politics is the determination of these values. To say that we can live our skepticism with regard to material objects is to say that we do not value things as we should, and we have turned the world into a vicious, inhuman place as result.

There is ample textual support for this political interpretation of skepticism [...] here are the broad outlines of my reasoning. First, there are suggestions in several of Cavell's writings, most patently in the introduction to Disowning Knowledge, that skepticism should be regarded as a historical event with its own unique genealogy, which includes, for instance, the emergence of science and the "death of god" (causes that are not exactly politically insignificant), and most relevant here, the birth of the idea of politics by consent. 39 While skepticism is not equivalent to democracy, its reinvention as a modern idea does coincide with the Enlightenment's rediscovery of government by the people. And skepticism is, for Cavell, perhaps all the more likely to assume tragic (which is to say, public) dimensions in a democratic society, a point I discuss at length in my reading of "The Avoidance of Love." This is also one reason why redemption from skepticism is so linked with the idea of America.

Second, in describing skepticism, Cavell uses words that, if not strictly political, are perhaps most common in such contexts (for example, "alienation"), and he quotes accounts from other authors that are meant politically (such as Thoreau's “quiet desperation”).

Third, and most important, Cavell's account of skepticism in Must We Mean What We Say? is itself developed through his discussions of Vietnam, racial inequality, and nuclear holocaust. In treating Cavellian skepticism as a political condition, I am, therefore, bringing the concept home.

My treatment of skepticism turns the redemptive claim to existence as a human subject into a simultaneous demand to have a political voice, which means, ha-

39. Cavell, Disowning Knowledge: In Seven Plays of Shakespeare (Cambridge: Cambridge University Press, 1987), 20-21. 
ving the right to revalue or to recount (things and people in) the world. The goal of Cavellian politics is not consensus, but rather an unauthorized census, carried out as a scene of confrontation where the goal is mutual acknowledgment. That is, politics for Cavell is a matter of counting, understood both transitively and intransitively. While this concept of census can concern all sorts of matters (What counts as a just war? What counts as equal opportunity? What counts as a marriage?), it is, first and foremost-and implicit in each of these questions-about who and what counts as political. Do you acknowledge me as a political subject, as one who can determine what counts (as a just war, as equal opportunity, as a marriage...)? Does my demand count for you as political or do you instead dismiss it (as criminal or immoral or puerile or sick)? Do I count for you? The claim to and demand for political status, for the right to count, thus accompanies every other political utterance-just as the cogito accompanies every physical perception for Descartes, so that I know, despite appearances, my own mind better than I know the sensuous objects around me. I establish and disclose my subjectivity-my voice-as the achievement of political action. The relevant dramatic medium here would be cinema, specifically Cavell's account of Hollywood stars in The World Viewed, the star being the one who is disclosed in exemplary cinematic performances with every character, in each line and glance and gesture (Bogart, for instance).40 Plots and roles remain significant: without them, stars would not be born; not because the stars were hidden from us, just waiting to be revealed, but because they become who they are only in those moments of mass seduction taking place there on the screen right before our eyes. The star is distinct from both actor and character, yet unthinkable without them: Bogart would not be Bogart without that voice, that glare, that impossible blending of intensity and indifference. Nor would Bogart be Bogart without the hard-boiled detectives and disappointed romantics and honorable swindlers that he brings to life. Danish princes would never do. It is the light of these stars refracted through the clichés of underwritten roles and overwrought plots that we as audience gaze at, mesmerized, so that the exemplary cinematic presentation of any world exceeds the sum of its script, projecting another world of fantasy coextensive with it and more singular than any boilerplate narrative could ever be. 
Every political presentation functions in the same way, disclosing both a demand and the subject issuing it, political subjectivity being, like stardom, distinct from the accidental features of biography and identity associated with the actor. It is why even politics without parties is bound to traffic in endless labels: a name, good or otherwise, is "the immediate jewel" of political utterance. The age-old political practice of name-calling is only the acknowledgment that our political positions make us who we are. Any political actor worth his salt knows that much is to be gained by those who filch good reputations by naming their enemies well.

Political census, as Cavell describes it, is by its very nature contentious, an ongoing, interminable argument. Since I am identifying the right to be one who (both transitively and intransitively) counts with our claim to exist as human subjects, then denying my place in this combative conversation of justice is a denial of my very humanity. Something like this idea is central to our concept of modern democracy, where rights are not only the possessions of the citizen, but the natural inheritance of every human being. While Cavell argues for this convergence by linking political conversation with human redemption, he does not consider it sufficiently enough, as in his discussion of slavery in The Claim of Reason, where slavery is taken to be a perverse acknowledgment of the slave's humanness, the slave owner being the one who imbrutes himself, who denies his own bond with humanity even while denying the slave participation in the conversation of justice.41 It is not that I oppose Cavell's reversal of the problem, which is consistent with the sense once captured in our language by the word brutalize, though that sense has now perhaps been lost in the endless stream of atrocities to which we have applied it. I do wish, however, to register this general objection. I do not dispute that the sadistic slave owner who tortures or rapes the slave acknowledges certain human features, in these cases the ability to suffer the pain and lust that he inflicts upon them. I do not doubt that he even recognizes himself in his victim, at least in these limited ways, and exploits the intimate knowledge that this grants him of a hidden maze of psychic pains and weaknesses. No one ever said sadists and psychopaths were not perceptive or cunning. But then, 
normal people also talk to horses and describe dogs as their best friends: our hate, like our love, can transgress the boundaries between species.

This point may be an obvious one: it has become a treacly cliché to speak of the dehumanizing of our enemies and our poor and our oppressed, as it has, conversely, become a sanctimonious cliché to remind others that the Russians (or whoever has replaced them as our foe) love their children as much as we do, as though that fact will be enough to make us toss away our guns once and for all. No, Cavell is right to say that there is a terrifying fact that we must all own up to in being human, namely that there is no limit to the horrors we are willing to inflict on other people. If only every day were Christmas, when, as an endless number of battlefield legends have it, the trenches fell silent while enemy armies that had been killing one another just a few hours earlier serenaded each other with carols across no man's land-only to replace the sound of song with the noise of bullets the next day. There is no end to the ways in which we deny others their voices; no end either to our means of imbruting ourselves. But does our altered sense of the word brutalization-our sense that it is now our victims who come out as something less than human in our assessmentsoffer a thread worth following?

Just look at the photos of the mangled bodies of children who have worked in mines or the sinewy scars on the backs of slaves and you cannot help but feel that this sentiment of pillaged, broken humanity, commonplace though it may be, is somehow correct. What Cavell adds to this cliché, though he fails to realize its implications in full, is a way to think through the power this sentiment has over us, along with our blindness to the ways in which we go on denying the humanity of others by ending or ignoring the conversation. Child labor and slavery are now too painful for our consciences to endure, but our deafness to countless others is not (yet).42

While participation in the conversation of justice thus occurs on two levels simultaneously-the human and the political-this convergence ceases to be, in my reading of Cavell, that of "man" and "citizen." The immigrant or exile, Cavell's words for the political subject, now displaces the citizen. But if skepticism means not being at home in the world, why should the immigrant or the exile be the redemptive political

42. I write this knowing that the "we" that I identify here is not as large a portion of humanity as I might like. 
subject rather than the very symbol of our estrangement? The answer is that our (American) settling into the world, as dramatized in Thoreau's project at Walden and captured in Emerson's idea of "abandonment," consists of "being on the road, on the way." 43 It is as though America's presence a world away from Europe made it, for Thoreau and Emerson, a place where stifling paradox became fruitful irony. I have said already that in Cavell's reading of them we return to the world through its revaluation, which is to say, its creation, its discovery as new. I will add now to this irony our achievement of intimacy through exile, and our redemption from alienation by becoming immigrants-immigrancy being Cavell's Emersonian "transfiguration” of our skeptical homelessness.44 The idea is clear enough as a reading of, say, Emerson's essay "Circles," where abandonment is taken as the human condition, the fact that "around every circle another can be drawn," so that the range of human experience is "god in nature [...] a weed by the wall." 45 Which is to say that we possess all the power and severity of the wild and of the divine: no walls can contain us, just as no borders can contain the immigrant or the exile. To accept limitation-the only sin, according to this defrocked preacher-is to deny our desire for the world, and thus to deny our humanness. But what could any of this mean politically?

I have said that having a home in the world means making a home, and making a home in a strange or foreign place is exactly what the immigrant or exile must do. Specifically, in politics the redemptive status of immigrancy or exile derives from the fact that political confrontation occurs, according to Cavell's inflection of utopia, in no place-as in "no place else," as in, here ... or anywhere.46 There is no proper setting for political exchange, so my staging of a demand is itself the creation of a political space, not according to some fixed idea, but as the creation and discovery of political action itself: my demand is not just raising a new issue, but inventing a new idea of-a new medium for-politics. The emancipation in the last two centuries of private life, of the worlds of labor and love, represents not just new causes and new laws, but the creation of new sites for the staging of acknowledgment. I do not refer here to the expansion of the established political realm, the absorption of private life by the pu-

43. Cavell, The Senses of Walden (Chicago: The University of Chicago Press, 1972), 29-30.

44. Cavell, "Emerson's Constitutional Amending," 211.

45. Emerson, "Circles," in Ralph Waldo Emerson: The Essential Writings, 252-62 (see n. 40), 255.

46. Cavell, Conditions Handsome and Unhandsome, 20. 
blic sphere, though this has clearly happened as well. I mean instead that what had been understood as the proper space of politics turned out to have no monopoly on acknowledgment, while in the dark, constricted recesses where, for centuries, people had toiled invisibly, content to be acknowledged only in the next world, human beings were reborn, demanding that the next world coincide with this one. In politics, at least, existence precedes essence.

Skepticism in its political form includes the sense that political action is impossible, and impossible because we do not know what it is or where to begin; we do not know how to offer our consent (or not). It is as though the terms of the social contract have been reversed, so that we live in a pre-political state of nature precisely because our society is so well ordered that it can get along just fine without our voices. But without my consent it is not a contract at all: it is a skeptics' conspiracy.47 As a political subject I thus feel compelled to stage my enactment of existence outside of all conventions, what Cavell names the order of law, either because I think this order is hopelessly compromised by injustice, or when this is not the case, because the order of law is only truly just-i.e., I only actively consent to it-when it is animated by my (human) desires. I become an immigrant or exile, convinced that a home for my desire must be made elsewhere, in a new world, a world that will be found and founded right here. In other words, consent is possible only by way of voicing my dissent, what Cavell calls, after Emerson, aversion. It means settling into my home, my society, by going into exile, by being on the road.

Being outside the order of law means that I risk unintelligibility, that I suffer accusations of childishness, madness, illness, perversity, criminality, or worse. I have no authority, no appeal, no claim to standing beyond a voice or the silent staging of my desire and my humanity. I may not even have an obvious grievance or injury that I can point to. Yet I feel wronged and wish to establish a new standard, surpassing that of my society, for measuring human justice. Risking unintelligibility in this realm of desire does not mean that I have given up on making myself understood-the despair that Bloom and Updike accuse Emerson of, or what Cavell will describe, after Wittgenstein, as the "fantasy" of a private language. On the contrary, I refuse despair by persisting in my attempt to achieve intelligibility outside of the available conditi- 
ons for political conversation, driven by the feeling that action and intelligibility are impossible within the order of law; not because the words I use are inadequate, but because my words and my life are now misaligned.48 My words continue to mean: $I$ do not. According to the order of law I am, as an exile, no one, which is precisely why I can speak for all, why, at that moment, "I stand for humanity."49 What I called Marx's cogito becomes this for Cavell: I am no one, and I speak as everyone.

The best example of the Cavellian political subject is Nora in Ibsen's $A$ Doll House.50 Of course, Nora leaves her husband Torvald, who can hear her only as a child, a hysteric who needs to be calmed, rather than a fully realized human being expressing a desire for change. The order of law she inhabits is compromised, and so she too is compromised, unable to be reborn within its confines, represented in this case as the house she inhabits, the house referred to in the play's title. She stages her desire by leaving it, by slamming the door behind her, an unspoken utterance that is the enactment of her existence. However loud that slamming door must sound to Torvald and to us as her audience, it is a silent show of desire that we must read. But must politics always entail slamming doors and other literal abandonments?

Above I said that it is not only when the order of law is hopelessly compromised by injustice that such enactments occur, that they are, on the contrary, ways of revitalizing the conversation of justice and showing that I consent to my society. My final chapter, which explores Cavell's engagement with Rawls in The Claim of Reason and the Carus Lectures, considers how such enactments, as forms of dissent, can contribute to the conversation of justice in societies that have, as Cavell calls it, "good enough justice," so that, while I stage my demand outside the order of law, I am not compelled to slam the door on it, to walk out on it altogether. In such a society, argument and confrontation make possible the conversation of justice by redirecting it away from the impersonal rules and political operations that have no need for my voice to scenes of mutual acknowledgment where the possibilities of language to recount the world are explored and contested. In such circumstances, dissent is not the mark of a society's failures, but a measure of consent to its mode of justice.

48. James Conant, "Must We Show What We Cannot Say?," in The Senses of Stanley Cavell, ed. Richard Fleming et al (Lewisburg: Bucknell University Press, 1989), 242-83. 49. Cavell, A Pitch of Philosophy, 5 .

50. My references to this play are all drawn from Henrik Ibsen, A Doll House, in Ibsen: Four Major Plays, Volume I, trans. Rolf Fjelde (New York: Signet Classics, 2006). 
The argument I have delineated here largely begins [...] with the dynamic of skepticism and redemption in relation to the three political issues I find in Must We Mean What We Say?: the threat of nuclear holocaust, the continued injustice of racial inequality, and the destructive madness of the war in Vietnam. Each of these issues is part of a larger claim that America is no place, in the dual sense of not existing and of being a utopia, the site of human redemption. Dramatically, Cavell's claim is that ours is a state of tragedy, our fate as a nation like that of Lear. Philosophically, Cavell shows that we cannot know in advance what counts as political, that political action and intelligibility are subjects of constant contestation [...].

I claim that Cavell seeks an alternative to this American tragic narrative in cinema and in Thoreau's Walden, a book written in response to the same political crisis of a nation tearing itself apart by expanding its powers and by failing to acknowledge a sizable segment of its population, which is to say, by failing to count properly. The important themes to emerge here are those of recounting or revaluing the world, and of our society as a parody of the social contract, what I have already referred to as a skeptics' conspiracy. Thoreau's prophetic persona, the dramatic mask or type that Cavell finds in Walden as an alternative to tragedy, also sets the stage for the remainder of my argument, where prophetic politics becomes what Cavell calls "passionate utterance," corresponding to the dramatic narratives of opera and melodrama [...].51

I show how passionate utterance figures in Cavell's engagement with Rawls, so that dissent forms the basis for a continued conversation of justice in the form of the interminable argument I have described. This drama of consent, as Cavell calls it, is a narrative of forgiveness corresponding to comedy in two ways. First, it is the drama of a society in which citizens can exercise their dissent freely, can show their aversion openly, as do all the quirky, amorous pairs that populate romantic comedies, or as the Marx Brothers do in their ecstatic eccentricities. These pairings and partnerships repudiate society's conspiracies by offering a model of genuine consent, while at the same time testing society's tolerance for aversive dissent (which is why so many romantic comedies feature brushes with the law, to say nothing of the Marx Brothers'

51. Cavell suggests that his notion of passionate utterance is the most politically relevant idea in his work, though what little explanation he gives differs from my own account. See Cavell, "The Incessance and the Absence of the Political," in The Claim to Community (see n. 17), 263-318. 
own adventures in that arena). Second, it is comedy that best shows us a world that refuses to conform to our ideas, a world as hostile to us as anything dreamt of in Descartes' first Meditation or Marx's haunted world in which commodities stalk us like zombies and "all that is solid melts into the air." It is in the comedian's world that every step is a pratfall, that every seat has a tack on it, and that our own bodies conspire against us-a rumbling stomach at the lothario's moment of seduction or our limbs becoming the tangled, heavy chains of that clumsy condition we call being human. Comedy is the knowledge, as hard as it is happy, that being human means being humbled. We all share in this knowledge because, living our skepticism, we experience a world pitched against us, mocking our presumptions of power and relishing our vulnerabilities. But the comic alone finds grace in such moments, showing us that the world is not to be recovered rapaciously, as in tragedy, but accepted in its risible unwieldiness, what Emerson calls its "lubricity." It is comedy, therefore, which teaches us to forgive the world for its rebuke of us, where forgiveness is not accommodation or resignation to the humiliations of being alive, but a refusal of despair in the face of them. Grief may make idealists of us all, as Emerson writes, but it is despair that will deflate our every ideal, which is why Emerson called on the American Scholar not to instruct, but to cheer us, and to cheer us not that we may escape from the ugly realities of the world, but that we may go on suffering them, confident that we may at last find the genius to match them, and in the end, claim some small victory for justice. $5^{2}$ 